\title{
BREXIT IMPACT ON SERBIAN ECONOMIC DEVELOPMENT
}

\author{
PhD Ljiljana Stošić Mihajlović, Professor \\ High School of Applied Studies, Vranje, Serbia, mihajlovicp@ptt.rs \\ MSc Ivana Zdravković \\ „Radoje Domanović“ School, Vranje, Serbia, elektrokontakt.vr@gmail.com
}

Professional Paper

doi:10.5937/jouproman4-11324

\begin{abstract}
On Thursday, 23.6.2016. the British were out to vote - a referendum to stay or exit from European Union nations. With minimal but sufficient majority pleaded United Kingdom leave European Union. The paradox is even greater because there are, the principles, and the chapters that each member state has to pass, and to harmonize its legislation and rules of good practice in force in the EU, but there are no rules to carry out, or how to handle the situation when the country decided by a majority vote of its population to leave the EU. However, what is for Serbia at this moment most important is how it will affect the flow Bregzit and Serbia's path towards the EU, in terms of whether and how much will be the consequences for Serbia in the light of recent events.
\end{abstract}

More important question is, it seems, refers to economic stability in Serbia. In this regard, the paper discusses the situation primarily on the economic front Serbia after the decision of Great Britain to leave the European Union. Special attention is paid to the opportunities that presented themselves in connection with a faster reception of Serbia in the EU or in the work also indicates the obstacles that Serbia will inevitably encounter on the road to the EU as a strategic orientation through and in a situation where the purpose and existence of the European Union questioned. However, the conclusion is that the citizens of Serbia needed strong EU compared to the one that has ever existed. EU, Brexit

Key words: Serbia, development, economy,

\section{INTRODUCTION}

According to the current EU Lisbon Treaty, each member who wishes to leave the union storage room should be to invite, or to activate Article 50 of the Agreement provides for a process which is the only exit from the EU, and this process is planned within two years. According to the EU economy, and consequently the economy Serbia, it would be good to Britain as soon as begin the process of leaving the Union and thus provide mechanisms to continue the EU accession process of Western Balkan countries, including Serbia.

Already, without doubt, be trusted to data on major economic losses are presented worldwide, primarily Economic Community, which indicates that after, we can say with certainty, the historic decision of the British to leave the European Union. The decision of Britain to leave the EU has led to serious problems and earthquakes on the international market, mainly in the capital market. Recently, in all the media published that only in one day 400 people are listed in order of the richest in the world, losing huge amounts of money, the estimates are even close to 128 billion dollars (Evaluation Agency "Bloomberg"). It is estimated that the richest lost more than $3 \%$ of the net capital, which in absolute figures is close to 4 trillion. Is Serbia affected breaking Britain with the EU remains to be seen. Leading experts in the field of economy in Serbia BREXIT soothe public that will not have negative effects on economic trends in Serbia. Even, it is anticipated that the new situation just to speed up the European integration and the accession of Serbia to the EU.

\section{INFLUENCE ON BREXITA GEOPOLITICAL CHAINS AND WORLD MARKET}

It is very important to look at all sides actual situation and the possible consequences of leaving Britain from the EU on the world market, primarily money market and capital. 
According to estimates, the greatest losses have the richest man in modern Europe, Amancio Ortega, who is in the media reported that he lost even more than 6 billion dollars!

Of course, until recently the richest man on the planet, Bill Gates - the founder and owner of "Microsoft's" not spared million British decision to say "No" to remain in the EU. In addition to these doubles billionaires, Vela has suffered damage to the first man, "Amazon-a" Jeff Bezos. For Bill Gates and Jeff Bezos estimates are that only a few days after BREXIT a whole after losing a billion dollars. The situation can be described in one sentence: billions of dollars disappear from the stock market! Now the world's experts and economic analysts are trying to project a situation that will arise over the next five years after the final exit of Britain from the EU. The President of the Council on Foreign Relations Richard Haas, predicted nothing rosy scenario for Britain in store for her in the next five years: Great Britain will impoverish, certainly comes to the change of Prime Minister (which in the meantime realized), further devalue the pound, and it will not weakens to a historical low, and it is now hard to accept, has predicts the disappearance of the United Kingdom - because Scotland will become independent and will join the European Union, while the Northern Ireland united with the Republic of Ireland, which is, in truth, it could be i expected.

In fact, the first steps towards the dissolution of the United Kingdom but also concretized. Scottish National Party leader Nikola Sturgeon, this match Announces another referendum for secession of Scotland from the UK and already lobbying in Brussels for EU support the intent to achieve a desirable and longawaited independence of Scotland. At the same time, we must not lose sight of the fact that Scottish with as many as $62 \%$ of the votes supported the Keep Britain in the EU. Research and results of the survey conducted by the "Squander post" suggests that more than $60 \%$ of Scots tomorrow voted for secession from the United Kingdom, a referendum would be held in the nearest future.

On the other side of the ocean, a leading economist and director of the Center for Economic and Policy Research in Washington Din Baker, optimistically viewed the new situation after a BREXIT on the world economic scene. According to him more over the next five months, the capital market will be stabilized enough that one can not speak of a recession, and after the presidential elections in November, which will be held in the US Britain will "stand on its feet" in the medium term of five years and Britain as well as the rest of the EU will reject austerity policies which should lead up to great economic growth.

Some analysts predict the flow of the world that Russia will try to regain its dominant influence over such countries as Hungary, Poland and the Czech Republic but also in the Netherlands. Such amounts primarily predictions senior officials from the CIA (John MekLafin, former director of the CIA). The impression is that analysts in the west of patience "triumph" of Russia because of the decision of the British to leave the EU. Many worried about the possible scenario that Russia could increase its influence in relation to NATO, primarily in Eastern Europe. The media can not hear or read a very direct views of the representatives of the ruling parties, as for example in Hungary, where incumbent Prime Minister Viktor Orban openly argues that the British wanted to leave the EU because they do not want to uncertainty and because "in Europe lost the order."

As for the leaders of the European Union, and that is unrivaled in the current balance of powers Germany, many, if not all, analysts predict that Germany will continue to maintain a leading position in the EU and will continue to "assess" EU in any regarding: economic and political. 
As the world's capital markets are concerned, the data show that the US dollar strengthened against the British pound, which will certainly help the US economy to avoid possible shocks and turbulence that will certainly shake the European capital market despite heavy intervention of the British central bank pumped a lot of money in order to stabilize the market.

When we talk about reactions in global stock markets, which are all of the order, after Brexit recorded a decline, it was expected given that the stock market such a market mechanism that responds appropriately to any type of political decisions, such as the decision on Brexit. Therefore, in the rest of the Stock Exchange believes that the infallible because they are traded on the expectations, where market participants extremely careful. In fact, the point is that the clubs business very sensitive to uncertainty and do not like the turbulence in the business world, so it is now an expectation to continue downward trend.

The President of the European Movement in the Republic of Serbia and economic expert Mihajlo Crnobrnja believes that the entry into the $\mathrm{EU}$ is precisely arranged, because he knows exactly how to access, but the problem arises because there is simply no defined exit because procedure there. In fact, there is only one member who said that the EU community from which they can get out. ${ }^{1}$

At a time when the fate of a united Europe on its turning point, the most influential European and German newspaper "Bild" they asked Serbian Prime Minister Vucic: Serbia where he was going? This question is all the more significant coming as it does from Germany's influential list of printed copies of which exceeds 2 million copies. But

In:http://www.b92.net/biz/vesti/srbija.php?yyyy=20 $16 \& \mathrm{~mm}=06 \& d d=23 \& n a v \_i d=1146865$ from the standpoint of Serbia is far more important that the public knows whether Serbia will consistently follow its path to the EU without NATO integration, and how it will manage to keep the macroeconomic stability achieved in conditions of great austerity and sacrifices of the citizens of Serbia. So, how interested the German response shown by the fact that the interview was published in more than two million copies weekly issue the highest circulation newspaper in Europe and a day before the summit of the Western Balkans in Paris, where he planned and meet Vucic and Chancellor Angela Merkel. Our Prime Minister has been consistent, he said: "Two months ago we had a kind of referendum - we had elections. I've won convincingly. The campaign never lied to the people. I told them that we want to maintain the best possible relations with Russia, China and the United States, but our strategic objective of the European Union. I repeated to 1,000 times. No lies, no misunderstanding. And people have voted for it. We had to keep the road to EU. If you miss it, Serbia will go in the wrong direction. That's it." ${ }^{2}$ Asked by reporters in the same interview that Prime Minister Vucic gave the German" Bild ", which was:" Angela Merkel is the most powerful, and most disputed politician in Europe. What do you think of her? "The prime minister said:" I believe in her responsible, serious and rational approach to the Balkan crisis. Without it, we might be in the Balkans faced many terrible challenges. But do not expect any gifts from Angela Merkel, neither of Germany ... If you look at the research in Serbia, five years ago, the popularity of Germany and the German Chancellor was 5 to 10 percent, and today is between 30 and 40 percent.

\footnotetext{
${ }^{2}$ http://www.blic.rs/vesti/politika/prelomni-dani-zasrbiju-vucic-ponavljam-1000-puta-idemo-uevropsku-uniju/7kqr5kk, access. 05.07. 2016.
} 
Angel a Merkel was among the three most popular leaders, and Germany among the three most popular countries in Serbia." 3

\section{BREXIT IMPACT ON ECONOMY SERBIAN}

Leading experts of Macroeconomic Analysis and Trends (MAT) assessed that the decision to exit the UK from the European Union or Brexit, in fact, had a particularly high impact on the economy of Serbia. Although, at first seemed to be a major cause Brexit, instability and fracture on the global financial market and that it will be based on the principle of communicating vessels and spill over to Serbia. Fortunately, of which none were. What certainly ahead is that analysts in Serbia closely monitor what happens on. As noted above, to date there have been no major disturbances and even the National Bank of Serbia on three occasions bought foreign currency at the interbank foreign exchange market. For economic stability in Serbia is most important to you will Brexit stop the restoration of economic activity in the EU, but also indirectly, will in any way affect the already recorded economic growth in Serbia.

Impact Brexit on economic trends in Serbia, which could have far-reaching negative effect relationships can be considered pessimistic variant view of the circumstances, but of course has an adequate degree of statistical probability, which should be taken. In fact, the probability of a pessimistic scenario will be much increased if the process Brexit in any way in the future period is delayed and challenges increase uncertainty and risk according to an analysis of MAT.

Although developments in the periphery of Europe and the world, mainly Serbia felt any negative development in the global economy, and our economists tend to say, no matter what happens in the international market is reflected on Serbia and often

\footnotetext{
${ }^{3}$ Ibidem
}

negative. ${ }^{4}$ Professors from the faculties of economics in the country have a balanced view that is important for Serbia what happens in the EU. Because it is not possible that the economy and the stability of the EU is deteriorating, and that Serbia is progressing. Unfortunately, the reverse may be because of the economic history so far so many times that revealed EU progress Serbia has a process of regression.

One is clearly well-known fact in the case Brexit or exit of Britain from the EU direct economic consequences for economic growth and to the Stability Serbia in the economic sense in any case would not have been so pronounced. The reason for this is primarily in the fact that Serbia is not exposed to the British pound, while the trade with that country girl. From the point of investment activities it is certain that British investments in Serbia are not nearly enough, nor are many.

However, Serbia will be felt to the economic consequences Brexit and through the fall of the currency and loans taken over in Swiss francs. The point is that the British pound has experienced a major decline after Brexit, which could affect the citizens who have borrowed in Swiss francs. Economic logic dictates that the devaluation of currencies such as the pound is causing an earthquake in the financial markets as it comes to the strengthening of the dollar and the French franc. Again, the economic logic imposed "escape" of savings from shedding pounds and to safer currencies, currently the Swiss franc and the US dollar. But in terms of economies of these countries (Switzerland and the US) that is not favorable situation, because these two countries are exportoriented, so that any unjustified strengthening of their currencies and reduce exports reflects poorly on their economy.

\footnotetext{
${ }^{4}$ http://www.blic.rs/vesti/ekonomija/ekonomistibregzit-nije-imao-veliki-uticaj-na-srbiju/16tjxsc, access: 06.07.2016.
} 
These trends in the financial markets have a negative aspect on express an opinion public debt of Serbia. Cold statistics record that is only within 2 days of the referendum in the UK Serbia's public debt rose to 228 million euro's. "The dollar debt of Serbia on the day of the British referendum on 23 June, was worth 8.04 billion euro's, and two days later, amounted to 8,232 billion euro's. This increase does not mean that Serbia will have to pay the amount of the debt increased, because after the "Brexit 'foreign exchange market has become very unstable, and the dollar, after a sharp jump, but slowly began to fall."

However, we can even talk about some positive effects on the economy of Serbia Brexit. Potential financial benefit of my Brexit to reach those citizens who have invested in the pound because it is very likely that the short-term shock in the near future to a large extent be brought into line.

Decrease in pounds of insignificant, even a marginal impact on the Serbian economy, because foreign trade with Britain small. On the other hand, Serbia's public debt is denominated in sterling and less than $0.5 \%$ of the total public debt of Serbia. An interesting result Brexit in terms of customs and tariff policy with Britain. Specifically, as a result of Brexit it is likely to lead to the introduction of tariffs on exports to the UK and vice versa. However, the negative effect would even in this case would be negligible and would not be affected to a greater extent, the reduction of trade, on the other hand would not have increased customs revenues. This is because only $1.5 \%$ of domestic merchandise exports are sold in the UK market.

In particular sales of goods and services in Serbia in the UK market in 2015 recorded 177 million, while the share of the United Kingdom to import our modest and amounted in the same period only $1.2 \%$, or 200 million eur.
The impact on the reduction of the inflow of foreign investment from the United Kingdom should not be significant if we take into account the fact that the former British investment to Serbia were negligible modest, only just over $1 \%$ of the total foreign investments in Serbia According to the data for the previous year.

\section{CONCLUSION}

From the economic and financial point of view, general conclusion is that the direct consequences on the economy and economic trends in Serbia can be given that we have extremely low trade with Britain, very few are in charge in pounds sterling, while the deposits in this currency are also negligible small.

Impact Brexit the Serbian economy will be more indirectly through channel developments in the European Union (EU), rather than directly through cooperation with Britain. It is certain that the risk to the Serbian economy has a negative impact Brexit the EU, given the high degree of integration of the Serbian economy with the economy of that country and across the block boundary and financial flows.

Events with Great Britain were brought uncertainty and fluctuations in the international market globally, which undoubtedly spill over to all economies in the world, to a greater or lesser extent. In this respect, Serbia is no exception to this integration. Great Britain is not in the group of important foreign trade partners. In the banking sector, we remind you, there is no capital who is originally from the $\mathrm{UK}$, or the exposure of the banking sector in the currency of the pound is weak. But if the dollar continued to strengthen, that would be bad for Serbia, because the public debt was therefore relatively higher. 
If we can talk about some advantages, it should be noted that the Serbian economy is much more related to the euro zone countries (Germany and Italy), and therefore considers that it should not feel significant effects Serbia leaving the UK from the EU (as it is not was in the Euro zone).

Central Bank of Serbia (NBS) announced that the movement of the exchange rate ungrateful to predict, but the release of a strong economy, what is British, from the EU, does not constitute a favorable circumstance, but this should not significantly determines the movement of the euro valuable asset in the long term. It is realistic to expect low levels of Euribor in the short term.

Larger Brexit result is called. Domini effect on other members of the EU, but it is certain that it will cause long term instability and uncertainty.

\section{REFERENCES}

1. http://www.ekapija.com/website/sr/page/1 480348/Negativne-posledice-Bregzitaoseti\%C4\%87e-i-Srbija-Na-udaru-kursdinara-krediti-u-\%C5\%A1 vajcarcimajavni-dug-dr\%C5\%BEave, pristup 06.07.2016.

2. http://www.blic.rs/vesti/politika/prelomnidani-za-srbiju-vucic-ponavljam-1000puta-idemo-u-evropsku-uniju/7kqr5kk, datum pristupa. 05.07. 2016.

3. http://www.blic.rs/vesti/ekonomija/ekono misti-bregzit-nije-imao-veliki-uticaj-nasrbiju/l6tjxsc, pristup: 06.07.2016.

4. http://www.b92.net/biz/vesti/srbija.php?yy $\mathrm{y}=2016 \& \mathrm{~mm}=06 \& \mathrm{dd}=23 \& n a v \_i d=1146$ 865 